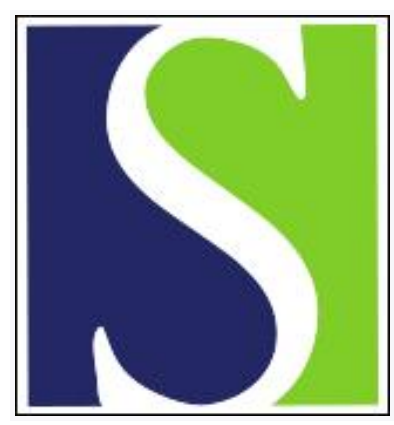

Scand J Work Environ Health 1981;7(2):114-118

https://doi.org/10.5271/sjweh.2558

Issue date: Jun 1981

Delivery outcome for women working in the pulp and paper industry.

by Blomqvist U, Ericson A, Källén B, Westerholm P

Key terms: delivery outcome; laboratory work; malformation; paper industry; perinatal death; pulp; woman; working

This article in PubMed: www.ncbi.nlm.nih.gov/pubmed/7313615

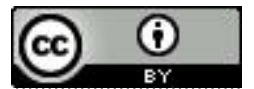




\title{
Delivery outcome for women working in the pulp and paper industry
}

\author{
by Urban Blomqvist, MD, ${ }^{1}$ Anders Ericson, MPolSc, ${ }^{2}$ Bengt Källén, $\mathrm{MD},{ }^{3}$ \\ Peter Westerholm, MD ${ }^{4}$
}

\begin{abstract}
BLOMQVIST U, ERICSON A, KÄLLEN B, WESTERHOLM P. Delivery outcome for women working in the pulp and paper industry. Scand $j$ work environ health 7 (1981) 114-118. A report on unusually many wasted pregnancies among women working at a laboratory in a paper industry gave rise to a cohort study on pregnancy outcome among all women working in the pulp and paper industry in Sweden during 1973-1977. A total of 890 deliveries were identified (899 infants born). The total number of malformed infants or perinatally dead infants was according to expectations. When the material was broken up according to occupation, it was found that, in the group of infants whose mothers worked in laboratories during pregnancy, the rate of malformed infants appeared high. These data, added to previously published data, seem to support the notion that work in laboratories represents a pregnancy hazard.
\end{abstract}

Key terms: laboratory work, malformation, perinatal death.

The possibility that occupation during pregnancy can represent a hazard to the developing embryo or fetus, resulting in miscarriage, malformation, or perinatal death, has to some extent been explored only during the past decade. In principle, two types of studies have been made. One starts with the malformed infants and studies the distribution of occupations among their mothers and compares it with a reference material $(3,7)$. The second type of study investigates pregnancy outcome in a cohort of women defined by occupation during pregnancy.

The former case-referent technique is the greatest help when an occupational exposure is a major cause of a specific malformation, notably when the malformation is rare. Such an example is given

1 Korsnäs-Marma Ltd, Gävle, Sweden.

2 National Board of Health, Bureau of Statistics PB3, Stockholm, Sweden.

3 Department of Embryology, University of Lund, Sweden.

4 LO (Swedish Trade Union Confederation), Stockholm, Sweden.

Reprint requests to: Prof Bengt Källén, Department of Embryology, Biskopsgatan 7, S-223 62 Lund, Sweden. by the observation, so far unverified, of an association between birth of infants with gastroschisis and maternal work in the printing industry (2).

The cohort technique is more suitable for an evaluation of possible risks associated with a specific occupation, but only relatively strong risks are likely to show up. The critical importance of the cohort size should also be kept in mind, congenital malformations being relatively rare events. Examples of such studies are those concerning women working in operating rooms [for a review, see Ericson and Källén (4)], women working in medical occupations (1), or women working in chemical research laboratories (8). So far, only relatively few such studies are available. The present paper concerns one on women employed in the pulp and paper industry in Sweden.

\section{Material and methods}

This study was initiated by a report from a laboratory belonging to this kind of industry stating that, of seven pregnancies during the period 1973-1977, three had ended in miscarriage, two with the birth 
of a normal child, and two with the birth of a child with severe malformations.

A cohort of women working in the pulp and paper industry was formed in the following way: A questionnaire was sent to the staff offices of the various local industries involved asking for information on all women who had taken maternity leave during the period 1 January 1972 to 31 December 1976. Their place of work and their occupation during pregnancy was also obtained according to a standardized categorization of the various jobs within the industry.

Each woman was identified by her tendigit personal identity number, unique for every Swedish citizen. By record-linkage, information on her pregnancy, on the delivery, and on the infant(s) born was obtained from the Medical Birth Register for the years 1973-1977. Among 895 deliveries stated to have occurred after 1 January 1973, 890 were identified in the Medical Birth Register; the remaining five probably had faults in their identification numbers.

The Medical Birth Register is a computerized register of the delivery records of all women giving birth in Sweden. It contains information on diseases during pregnancy, complications during delivery, and diagnoses of the infant, including diagnoses of malformations according to the Swedish five-digit version of the International Classification of Diseases (ICD).

The infants were studied from two points of view: presence of malformation diagnoses (chapter 14 in ICD 8) and survival of perinatal period (first $7 \mathrm{~d}$ of life). The frequency of malformation diagnoses given varied markediy between different hospitals, mainly because of differences in the recording of minor malformations, but the hospital-specific rates are known from the Register. As the distribution of deliveries of the cohort among the different hospitals was known, this variability could be corrected for, and the expected number of malformed infants could be calculated on the supposition that the cohort was a random sample from the total population of these delivery units. Similarly, the expected number of perinatally dead infants could be calculated according to maternal age and parity distribution. All "expected" fligures given are based on such corrections.

\section{Results}

Table 1 summarizes the obtained results. The 890 deliveries resulted in the birth of 899 infants, seven pairs of twins and one set of triplets included. Perinatal mortality amounted to 8 infants, a number slightly below the expected 11 .

Forty-nine infants had one or more malformation diagnoses, the expected number being 50 , and only one malformed infant died (anencephaly). Among the 49 infants, 19 had major malformations. Table 2 specifies the malformation diagnoses given.

The total outcome of this cohort was thus very close to the expected one. How-

Table 1. Summary of material according to pregnancy outcome.

\begin{tabular}{|c|c|c|c|c|c|c|c|}
\hline $\begin{array}{l}\text { Year of } \\
\text { birth }\end{array}$ & $\begin{array}{c}\text { Number of } \\
\text { births }\end{array}$ & $\begin{array}{l}\text { Number of } \\
\text { infants }\end{array}$ & $\begin{array}{l}\text { Number of } \\
\text { stillbirths }\end{array}$ & $\begin{array}{c}\text { Number of } \\
\text { neonatal } \\
\text { deaths }\end{array}$ & $\begin{array}{c}\mathrm{Nu} \\
\text { infe } \\
\mathrm{me} \\
\mathrm{t}\end{array}$ & $\begin{array}{l}\text { nber of } \\
\text { hts with } \\
\text { forma- } \\
\text { ons a }\end{array}$ & $\begin{array}{l}\text { Number of } \\
\text { infants with } \\
\text { major mal- } \\
\text { formations }\end{array}$ \\
\hline $\begin{array}{l}1973 \\
1974 \\
1975 \\
1976 \\
1977\end{array}$ & $\begin{array}{r}178 \\
192 \\
234 \\
263 \\
23\end{array}$ & $\begin{array}{c}179 \\
196 \\
235 \\
266 \mathrm{c} \\
23\end{array}$ & $\begin{array}{l}2 \\
1 \\
1 \\
1 \mathrm{~d}\end{array}$ & $\begin{array}{l}2^{b} \\
1\end{array}$ & $\begin{array}{r}7 \\
7 \\
17 \\
16 \\
2\end{array}$ & $\begin{array}{r}(9.2) \\
(9.5) \\
(15.0) \\
(15.1) \\
(1.4)\end{array}$ & $\begin{array}{r}3 \\
3 \\
10\end{array}$ \\
\hline Total & 890 & 899 & 5 & 3 & 49 & $(50)$ & $16 \quad(16)$ \\
\hline
\end{tabular}

a Figures within parentheses give expected numbers corrected for distribution between delivery units.

b Twins.

c One triplet birth included.

d Anencephaly. 
ever, it contained women with very different occupations. In the original questionnaire, a subdivision was made of occupation according to nine groups, but some women had held more than one of these occupations during their pregnancy. Table 3 shows the distribution of all pregnancies between the differen't categories, and the distribution of the women who gave birth to infants with major malformations or to infants that died during the perinatal period.

In all, 162 women worked in laboratories during their pregnancy, six of whom had infants with major malformations (expected number 2.9). It should be noted, however, that the two women who gave the "signal" to this study were included in this group. Among the other infants, one had an anencephaly, one had a cleft palate,

Table 2. Malformation diagnoses recorded in the Medical Birth Register.

\begin{tabular}{lllr}
\hline $\begin{array}{l}\text { Group of mal- } \\
\text { formations }\end{array}$ & ICD code a & Diagnosis & $\begin{array}{c}\text { Number of } \\
\text { infants }\end{array}$ \\
\hline Major & 740.99 & Anencephaly & 1 \\
& 746.19, etc & $\begin{array}{l}\text { Congenital heart defect: transposition of great } \\
\text { vessels, etc }\end{array}$ & 1 \\
& 746.99 & Congenital heart defect: unspecified & 4 \\
& 749.00 & Cleft palate & 1 \\
& 749.20 & Unilateral cleft lip/palate & 2 \\
& 750.00 & Tongue malformation & 1 \\
& 750.28 & Esophageal atresia & 1 \\
& 751.29 & Multiple malformation, including anal atresia b & 1 \\
& $751.50+753.01$ & Colon atresia, unilateral kidney aplasia b & 1 \\
& 752.69 & Malformation of female external genitals & 1 \\
Minor & 754.00 & Pes equinovarus adductus & 1 \\
& 759.00 & Situs inversus & 1 \\
& 745.10 & Preauricular tags & 3 \\
& 746.90 & Suspected cardiac defect & 2 \\
& 752.10 & Retention of testicle & 3 \\
& 752.40 & Hydrocele testis & 7 \\
& 754.02 & Pes calcaneo-valgus & 2 \\
& 755.6 & Preluxation of hip & 15 \\
\hline
\end{tabular}

a Swedish five-digit modification of the International Classification of Diseases (ICD) code.

b These infants were initially reported in the "signal" which caused the study.

Table 3. Distribution of cohort women and women with severely malformed infants or perinatally dead infants according to occupation during pregnancy.

\begin{tabular}{|c|c|c|c|c|c|}
\hline \multirow{2}{*}{ Occupation } & \multirow{2}{*}{$\begin{array}{l}\text { Percentage of } \\
\text { all women }\end{array}$} & \multicolumn{2}{|c|}{ Major malformations } & \multicolumn{2}{|c|}{ Perinatal deaths } \\
\hline & & Number & Percent & Number & Percent \\
\hline Office work & 380 & 2 & 0.5 & 1 & 0.3 \\
\hline Converting industry & 176 & 7 & 4.0 & 3 & 1.7 \\
\hline Other factory & & & & & \\
\hline Pulp industry & 17 & 1 & & & \\
\hline Paper industry & 136 & & & 1 & \\
\hline Total & 150 & 1 & 0.7 & 1 & 0.7 \\
\hline Laboratory work & & & & & \\
\hline $\begin{array}{l}\text { Pulp industry } \\
\text { Paper industry }\end{array}$ & 50 & 2 & & 1 & \\
\hline $\begin{array}{l}\text { Paper industry } \\
\text { Other (eg, research) }\end{array}$ & $\begin{array}{l}54 \\
58\end{array}$ & 1 & & 2 & \\
\hline Total & 162 & 6 & 3.7 & 3 & 1.9 \\
\hline Other and mixed & 22 & & & & \\
\hline Total & 890 & 16 & 1.8 & 8 & 0.9 \\
\hline
\end{tabular}


and two had cardiac defects. Two of these women (those who gave the "signal") shared the laboratory environment.

A total of 176 women worked during their pregnancies in "converting," that is, in the further refinement of the paper into various products, eg, board. Seven of these women had infants with major malformations ( 3 expected). Only three of these women were exposed to chemicals in their work. One woman, who had a child with a cleft lip, worked in a factory producing paper napkins and was exposed to various stains. Another woman with a child with a cleft lip was exposed to ethyl acetate. The third woman, whose child had a complex cardiac defect, was exposed to glue early during her pregnancy. In this group of women, three had perinatally dead infants - none of these women had been exposed to chemicals during pregnancy, but one had arterial hypertension.

\section{Discussion}

The present study is based on two sources of information, lists of women who, within the specified industry, had had maternity leave and the Medical Birth Register, containing computerized delivery records of all women delivered in Sweden since 1 January 1973. There were certain errors in these materials. One was a lack of relevant diagnoses in the Medical Birth Register. Only diagnoses given during the first week of life are included in the Register, and deviations noticed later, eg, malformations of internal organs or devel- opmental defects, including mental retardation, could not be studied. It is also known that incomplete reporting occurs even of major malformations (5). There is no reason why the present study group of women should differ from that point of view from the general population with which all comparisons were made.

Since the rate of malformed and/or perinatally dead infants in this study was approximately the same among the offspring of women working in offices or in the general factories, the environment of the paper and pulp industry does not seem to represent any significant reproductive hazards from the points of view studied. One should remember, however, that in the latter group only one infant had a major malformation and one was perinatally dead - these occurrences might well represent random underestimates of actual risks present.

The finding of a possibly increased rate of malformed infants among the offspring of women working in the laboratories congrues with other published data in the literature. Table 4 summarizes some studies which we have made with a similar study design (therefore a pooling of the data might be considered). There is a total increase in malformation rate in this group of infants, but most noticeably there is an astonishingly high incidence of two types of malformation, cleft lip with or without cleft palate and atresia of the gut (esophageal atresia included). Combined, these data suggest that the chemical laboratory environment can at least sometimes represent a hazard for the unborn infant.

Table 4. Summary of some studies on infants born to women working in chemical laboratories during pregnancy.

\begin{tabular}{lcccc}
\hline $\begin{array}{l}\text { Source and } \\
\text { reference }\end{array}$ & $\begin{array}{c}\text { Number of } \\
\text { infants }\end{array}$ & $\begin{array}{c}\text { Number of major } \\
\text { malformations }\end{array}$ & \begin{tabular}{c} 
Number of specific malformations \\
\cline { 4 - 5 }
\end{tabular} & $\begin{array}{c}\text { Cleft lip (palate) } \\
\text { Gut atresia }\end{array}$ \\
\hline $\begin{array}{l}\text { Pharmaceutical industry } \\
\text { Uppsala university (8) }\end{array}$ & 103 & 6 & 2 & 1 \\
$\begin{array}{l}\text { Lund university } \\
\text { (Källén, unpublished results) }\end{array}$ & 38 & 11 & 1 & 4 \\
$\begin{array}{l}\text { Present study } \\
\text { Total }\end{array}$ & 548 & 1 & 1 & 2 \\
\hline $\begin{array}{l}\text { Expected } \\
\text { p-value (one-sided Poisson distribution) }\end{array}$ & 6 & 24 & 5 & 7 \\
\hline
\end{tabular}




\section{References}

1. Baltzar B, Ericson A, Källén B. Delivery outcome in women employed in medical occupations in Sweden. J occup med 21 (1979) 543-548.

2. Erickson JD, Cochran WM, Anderson CE. Birth defects and printing. Lancet 1 (1978) 385.

3. Erickson JD, Cochran WM, Anderson CE. Parental occupation and birth defects: A preliminary report. Contrib epidemiol biostat 1 (1979) 107-117.

4. Ericson A, Källén B. Survey of infants born in 1973 or 1975 to Swedish women working in operating rooms during their pregnancies. Anest analg (Cleveland) $\mathbf{5 8}$ (1979) $302-305$.

Received for publication: 16 December 1980
5. Ericson A, Källén B, Winberg J. Surveillance of malformations at birth: A comparison of two record systems run in parallel. Int $\mathrm{j}$ epidemiol 6 (1977) 35-41.

6. Hansson E, Jansa S, Wande $H$, Källén $B$, Östlund E. Pregnancy outcome for women working in laboratories in some of the pharmaceutical industries in Sweden. Scand $j$ work environ health 6 (1980) 131-134.

7. Hemminki K, Mutanen P, Luoma K, Saloniemi I. Congenital malformations by the parental occupation in Finland. Int arch occup environ health 46 (1980) 93-98.

8. Meirik O, Källén $B$, Gauffin U, Ericson A. Major malformations in infants born of women who worked in laboratories while pregnant. Lancet 2 (1979) 91. 